\title{
Pengukuran Tingkat Kepuasan Wisatawan terhadap Fasilitas Wisata di Pantai Lasiana
}

\section{Measurement of Tourist Satisfaction Level on Tourism Facilities in Lasiana Beach}

\author{
Ronald P. C. Fanggidae ${ }^{1, a)}$ \& Maria Leliana R. Bere ${ }^{1, b)}$ \\ ${ }^{1)}$ Prodi Manajemen, Fakultas Ekonomi \& Bisnis, Universitas Nusa Cendana, Kupang.
}

Koresponden : ${ }^{a)}$ ronaldfanggidae@staf.undana.ac.id \& ${ }^{b}$ lelianabere@gmail.com

\begin{abstract}
ABSTRAK
Penelitian ini dilakukan untuk mengetahui kepuasan pengunjung terhadap fasilitas wisata di Pantai Lasiana. Penelitian ini termasuk jenis penelitian deskriptif. Metode penelitian yang digunakan dalam penelitian ini yaitu metode pendekatan kuantitatif dan kualitatif. Teknik sampel yang digunakan adalah accidential sampling. Sampel yang diambil sebanyak 100 responden yaitu wistawan yang berkunjung ke Pantai Lasiana. Pengumpulan data menggunakan kuisioner (angket), observasi dan studi kepustakaan. Analisis data menggunakan Importance Performance Analysis (IPA). Hasil penelitian menunjukkan tingkat kepuasan konsumen senyatanya lebih rendah dibandingkan dengan tingkat harapan. Hal ini berarti secara keseluruhan pengunjung belum sepenuhnya merasa puas dengan fasilitas wisata yang ada di Pantai Lasiana. Berdasarkan analisis diagram kartesius, fasilitas wisata yang masuk dalam prioritas utama dan memiliki kinerja yang rendah terdiri dari kondisi fisik lopo, kondisi fisik tempat sampah, ketersediaan jumlah tempat sampah dan pemisahan jenis tempat sampah organik dan non organik perlu diperbaiki agar dapat meningkatkan kepuasan wisatawan di masa mendatang.
\end{abstract}

Kata Kunci : manajemen infrastruktur \& fasilitas, kepuasan, fasilitas wisata.

\section{PENDAHULUAN}

Pada saat ini, melakukan perjalanan wisata merupakan salah satu kebutuhan yang harus dipenuhi, terutama bagi penduduk dari negara-negara yang telah maju.Pariwisata merupakan aktivitas, pelayanan dan produk hasil industri pariwisata yang mampu menciptakan pengalaman perjalanan bagi wisatawan. Unsur pembentuk pengalaman wisatawan yang utama adalah adanya daya tarik dari suatu tempat atau lokasi (Muljadi, 2012). Berkembangnya suatu usaha pariwisata tidak terlepas dari adanya dukungan prasarana, daya tarik obyek wisata itu sendiri dan usaha pendukung lainnya, mengingat karekteristik pariwisata yang memiliki banyak dimensi (Muljadi, 2012). Persepsi wisatawan dalam mengkonsumsi produk dan jasa selama wisatawan berkunjung ke beberapa destinasi akan dipengaruhi oleh perbedaan fasilitas, daya tarik wisata dan pelayanan di masing-masing destinasi. Dalam hal ini puas dan tidak puasnya wisatawan berkunjung ke suatu destinasi wisata tergantung dari daya tarik wisata dan fasilitas layanan yang ada di destinasi tersebut.Fasilitas atau sarana penunjang sangat penting untuk kebutuhan wisatawan sewaktu-waktu diperlukan, sehingga dengan tersedianya sarana penunjang akan lebih membantu memperlancar perjalanan. Sejalan dengan penelitian Susetyarini \& Masjhoer (2018) peningkatan kualitas fasilitas wisata diharapkan sejalan dengan meningkatnya kepuasan wisatawan yang berkunjung ke suatu destinasi wisata, dimana kepuasan wisatawan adalah salah satu tolak ukur keberhasilan suatu daya tarik wisata. 
Pantai Lasiana merupakan salah satu destinasi wisata unggulan di Kota Kupang, yang dikelola Secara resmi oleh Dinas Pariwisata NTT berdasarkan Surat Keputusan Gubernur Kepala Daerah Tingkat 1 NTT Nomor : 232/SKEP/HK/1993 tentang penunjukan Dinas Pariwisata Provinsi Daerah Tingkat 1 NTT sebagai pengelola obyek wisata Pantai Lasiana dan menjadikannya obyek wisata Kota Kupang yang dapat diakses oleh masyarakat umum mulai sekitar tahun 1970-an dengan membangun beberapa fasilitas umum didalam area wisata pantai Lasiana sebagai bangunan penunjang.

Pantai Lasiana mempunyai kawasan dengan luas lahan sekitar 3,5 hektar. Pada bagian barat pantai terlihat daratan yang membentuk bukit kecil. Bukit kecil ini menjadi latar belakang yang menambah keindahan Pantai Lasiana. Di atas lahan pantai ini ditumbuhi banyak pohon kelapa dan juga tanaman lontar juga terdapat lopo-lopo yang dibangun menyerupai pondok tradisional khas Timor. Selain menyaksikan dan menikmati keindahan Pantai Lasiana, wisatawan juga disuguhi kuliner khas NTT yang ditawarkan puluhan pedagang di kios-kios yang dibangun pemerintah, seperti jagung bakar, pisang gepe, dan kelapa muda. Berikut data kunjungan wisatawan Pantai Lasiana selama empat tahun terakhir, dapat di lihat pada Tabel 1.

Tabel 1. Daftar Kunjungan Wisatawan Pantai Lasiana

\begin{tabular}{cccc}
\hline & \multicolumn{2}{c}{ Kunjungan Wisatawan } & \\
\cline { 2 - 3 } Tahun & Mancanegara & Lokal & Total \\
\hline 2015 & 851 & 29.553 & 30.404 \\
\hline 2016 & 1.177 & 27.225 & 28.402 \\
\hline 2017 & 1.209 & 39.550 & 40.759 \\
\hline 2018 & 996 & 29.189 & 30.185 \\
\hline Total & $\mathbf{4 . 2 3 3}$ & $\mathbf{1 2 5 . 5 1 7}$ & $\mathbf{1 2 9 . 7 5 0}$ \\
\hline Sumber Dinas Pariwisata Provinsi $N T T, 2019$ & &
\end{tabular}

Dari Tabel 1 diatas dilihat juga bahwa jumlah kunjungan wisatawan ke Pantai Lasiana cenderung menurun setelah mengalami kenaikan pada tahun 2017. Hal ini disebabkan oleh keterbatasan fasilitas wisatadan kurangnya perawatan fasilitas-fasilitas yang ada. Oleh karena itu pemerintah perlu memenuhi segala kekurangan yang ada. Selain itu pemerintah juga harus terus berpartisipasi dalam mengembangkan serta menjaga obyek wisata Pantai Lasiana. Hal ini sangat penting untuk diperhatikan karena walaupun terjadi penurunan yang sangat tinggi pada tahun 2018 Pantai Lasiana tetap di kunjungi para wisatawan. Pihak pemerintah juga harus mampu memahami keinginan-keinginan wisatawan serta mempelajari faktor-faktor yang dapat mempengaruhi kepuasan para wisatawan dengan menambah berbagai fasilitas yang meningkatkan daya tarik wisata Pantai Lasiana sehingga dapat memberi kepuasan maksimal bagi para wisatawan yang berkunjung. Fasilitas harus dikelola dengan baik agar selalu bisa berfungsi dengan baik, sesuai dengan prinsip dasar Manajemen Aset Fasilitas (Soemitro \& Suprayitno, 2018).

Berdasarkan permasalahan diatas, tujuan dalam penelitian ini yaitu, untuk mengetahui kualitas fasilitas wisata di Pantai Lasianadan untuk mengetahui tingkat kepuasan wisatawan yang berkunjung di Pantai Lasiana.

\section{Kepuasan Wisatawan}

Kepuasan wisatawan adalah perasaan senang atau kecewa seseorang yang berasal dari perbandingan antara kesannya terhadap hasil suatu produk dan harapan-harapannya (Payangan: 2014). Engel dalam Payangan (2014) mengartikan kepuasan adalah "perasaan senang atau kecewa seseorang yang berasal dari perbandingan antara kesannya terhadap hasil suatu produk dan harapan-harapannya". Selanjutnya Suryadana \& Octavia (2015) menjelaskan bahwa apabila hasil produk lebih rendah dari harapan maka wisatawan merasa tidak puas, apabila hasil 
produk sesuai harapan maka wisatawan merasakan puas, dan apabila hasil produk melebihi harapan maka wisatawan akan merasa sangat puas.

\section{Fasilitas Wisata}

Fasilitas menurut Kamus Besar Bahasa Indonesia adalah sesuatu yang dapat membantu memudahkan sesuatu. Fasilitas bisa pula dianggap sebagai suatu alat. Fasilitas wisata merupakaan sarana yang bertujuan untuk melayani dan mempermudah kegiatan atau aktivitas pengunjung atau wisatawan yang dilakukannya untuk mendapat pengalaman rekreasi (Marpaung, 2002). Menurut Spillane (1994:67) fasilitas wisata merupakan sarana dan prasarana yang mendukung operasional objek wisata untuk mengakomodasi segala kebutuhan wisatawan, tidak secara langsung mendorong pertumbuhan tetapi berkembang pada saat yang sama atau sesudah atraksi berkembang.

Menurut Bukart \& Medlik (1974) dalam Ali (2016) fasilitas bukanlah merupakan faktor utama yang dapat menstimulus kedatangan wisatawan ke suatu tempat wisata. Akan tetapi ketiadaannya dapat menghalangi wisatawan dalam menikmati atraksi wisata. Maka dari itu fasilitas sangat dibutuhkan sebagai upaya dalam melayani dan mempermudah kegiatan atau aktivitas wisatawan di tempat yang mereka kunjungi.

Menurut Sumayang (2003:124) menjelaskan beberapa indikator yang perlu diperhatikan dalam penyediaan fasilitas antara lain :

1. Kelengkapan, kebersihan, dan kerapian fasilitas yang ditawarkan.

Keadaan fasilitas perusahaan yang dilengkapi oleh atribut yang menyertainya dan didukung dengan kebersihan dan kerapian saat konsumen menggunakan fasilitas tersebut.

2. Kondisi dan fungsi fasilitas yang akan ditawarkan.

Fasilitas yang berfungsi dengan baik dan tidak mengalami kerusakan.

3. Kemudahan menggunakan fasilitas yang ditawarkan.

Fasilitas yang ditawarkan kepada konsumen adalah fasilitas yang sudah familier bagi konsumen sehingga konsumen dapat menggunakannya dengan mudah.

\section{Jenis-jenis Fasilitas Wisata}

Menurut Mill (2000) komponen dari fasilitas perjalanan terdiri dari unsur alat transportasi, fasilitas akomodasi, fasilitas makanan-minuman dan fasilitas yang lainnya sesuai dengan kebutuhan perjalanan. Adapun Fasilitas terbagi sebagai berikut:

1. Tempat makan dan minum, tentu saja dalam melakukan kunjungan ke tempat wisata para wisatawan yang datang memerlukan makan dan minum sehingga perlu disediakannya pelayanan makanan dan minuman. Yang termasuk dalam layanan ini yaitu restoran, coffe shop, snack bar, dan lain-lain. Hal yang perlu dipertimbangkan yaitu jenis makanan dan minuman, ke-higienisan, pelayanan, harga, bahkan lokasi pun menjadi salah satu faktor untuk meningkatkan kunjungan wisatawan.

2. Fasilitas umum di lokasi wisata, fasilitas umum yang dimaksud adalah fasilitas penunjang tempat wisata seperti toilet umum, tempat parkir, pos penjagaan dan layanan informasi, musholla, dll.

\section{Kerangka Pemikiran}

Fasilitas wisata adalah salah satu hal yang memenuhi kebutuhan wisatawan yang melakukan perjalana wisata sesampainya mereka di tempat wisata. Dengan adanya fasilitasfasilitas tersebut juga diharapkan dapat membuat wisatawan merasa lebih nyaman dan tinggal lebih lama serta memberikan kesan yang baik tehadap daya tarik wisata yang dikunjunginya. Bentuk fasilitas wisata dalam suatu destinasi wisata dapat berupa akomodasi, tempat makan dan minum dan fasilitas umum yang menunjang kegiatan atau aktivitas ada pada obyek wisata tersebut. 
Bertolak dari uraian kerangka berpikir diatas, maka untuk lebih jelasnya pemikiran tersebut akan dipaparkan di Gambar 1 dibawah ini.

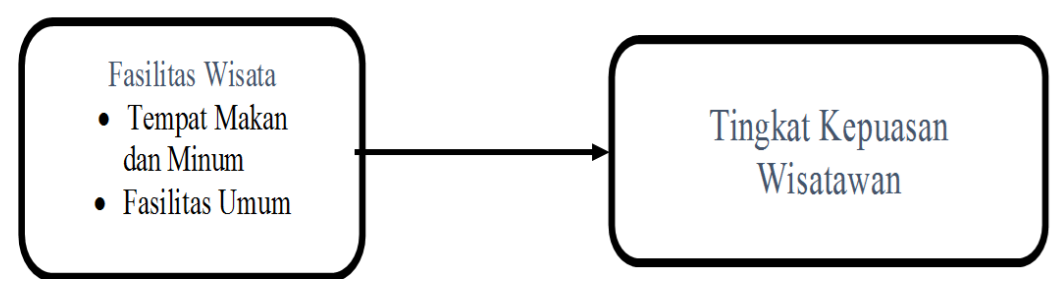

Gambar 1. Kerangka Pemikiran

\section{METODE PENELITIAN}

\section{Pendekatan Penelitian}

Jenis penelitian dalam penelitian ini penelitian deskriptif yaitu memberi gambaran atau menganalisis suatu hasil penelitian tetapi tidak digunakan untuk membuat kesimpulan yang lebih luas (Sugiyono, 2005). Pendekatan yang digunakan dalam penelitian ini adalah pendekatan kuantitatif dan kualitatif. Penelitian pendekatan kuantitatif dalam bentuk data dan kemudian dijabarkan dalam bentuk kualitatif. Kualitatif adalah mendeskripsikan hubungan antara fenomena yang diteliti dengan sistematis, faktual, dan akurat, sifat-sifat serta hubungan antara fenomena yang diselidiki (Kusmayadi \& Sugiarto, 2000). Lingkup penelitian ini untuk mengetahui tingkat kepuasan wisatawan terhadap fasilitas wisata di Pantai Lasiana.

\section{Populasi dan Sampel}

Populasi adalah wilayah generalisasi yang terdiri atas obyek/subyek yang mempunyai kuantitas dan karakteristik tertentu yang diterapkan oleh peneliti untuk dipelajari dan kemudian ditarik kesimpulan (Sugiyono, 2016). Yang menjadi populasi dalam penelitian ini adalah seluruh wisatawan yang berkunjung ke Pantai Lasiana.

Sampel adalah bagian dari jumlah dan karakteristik yang dimiliki populasi tersebut. Teknik pengambilan sampel yang digunakan dalam penelitian ini adalah accidential sampling yaitu siapa saja yang secara kebetulan bertemu dengan peneliti dapat digunakan sebagai sampel, apabila orang yang kebetulan ditemui itu cocok sebagai sumber data (Sugiyono, 2005).

Pengambilan sampel dalam penelitian ini disesuaikan dengan teori Roscoe (Sugiyono, 2016) bahwa ukuran sampel yang layak dalam penelitian minimal adalah 30 sampai dengan 500. Dengan pertimbangan lokasi penelitian, waktu, tenaga, kemudahan dalam menganalisis data dan pertimbangan biaya maka peneliti mengambil sampel sebanyak 100 orang yaitu wisatawan yang sedang berkunjung ke Pantai Lasiana baik itu wisatawan asing maupun wisatawan lokal.

\section{Teknik Pengumpulan Data} berikut.

Dalam penelitian ini pengumpulan data dilakukan melalui beberapa teknik sebagai

1. Observasi

Teknik pengumpulan data berupa pengamatan yakni dengan mendatangi langsung lokasi objek penelitian ke mudian mengamati langsung objek yang diteliti. Teknik ini menggunakan bantuan alat indra pendengaran dan penglihatan terhadap fenomena sosial dan gejala-gejala yang terjadi. Peneliti akan melakukan pengamatan langsung di kawasan Obyek Wisata Pantai Lasiana untuk melihat daya tarik wisata dan fasilitas layanan yang terdapat di sana. 
2. Kuisioner

Pengumpulan data dengan cara menyebarkan daftarpertanyaan kepada responden yang dijadikan sebagai sampel penelitian. Kuesioner merupakan teknik pengumpulan data yang efisien bila peneliti tahu dengan pasti variabel yang akan diukur dan tahu apa yang bisa diharapkan dari responden. Dalam penelitian ini skala pengukuran yang digunakan adalah skala Likert (Isgiyanto, 2009).

\section{Uji Instrumen Penelitian}

Dalam penelitian ini menggunakan kuisioner sebagai skala pengukuran variable penelitian. Kriteria kuisioner yang baik salah satunya memenuhi validitas dan reabilitas.

1. Uji Validitas

Menurut Ghozali dalam Arikunto (2002) uji validitas adalah suatu alat yang digunakan untuk mengukur sah atau valid tidaknya suatu kuesioner. Kuesioner dikatakan valid jika pertanyaan pada kuesioner mampu mengungkapkan sesuatu yang akan diukur oleh kuesioner. Pengujian validitas dilakukan dengan menggunakan program SPSS. Koefisien $r$ hitung harus dibandingkan dengan nilai $r$ tabel product moment dengan taraf signifikansi sebesar 5\%. Bila $\mathrm{r}$ hitung $>\mathrm{r}$ tabel, maka dikatakan item pertanyaan valid. Bila $\mathrm{r}$ hitung $<\mathrm{r}$ tabel, maka dikatakan item pertanyaan tidak valid.

2. Uji Reliabilitas

Uji reliabilitas adalah suatu ukuran yang menunjukkan sejauh mana hasil pengukuran tetap konsisten bila dilakukan pengukuran dua kali atau lebih terhadap gejala yang sama dengan alat pengukur yang sama pula (Isgiyanto, 2009). Suatu kuesioner dikatakan reliabel atau handal jika jawaban seseorang terhadap pernyataaan adalah konsisten atau stabil dari waktu ke waktu. Pengambilan keputusan berdasarkan jika nilai Alpha Cronbach > 0,6, maka pertanyaan variabel tersebut reliabel dan sebaliknya. Pengujian reliabilitas dilakukan dengan bantuan komputer menggunakan program SPSS.

\section{Teknik Analisis Data}

Metode analisis yang digunakan untuk mengetahui tingkat kepuasan wisatawan dalam penelitian ini yaitu analisis Importance performance Analysis (IPA). Analisis IPA digunakan untuk mengukur tingkat kepuasan wisatawan terhadap kinerja pihak lain, dalam hal ini yaitu peningkatan kualitas fasilitas wisata. Penelitian tingkat kesesuaian dan hasil penilaian kinerja maka dihasilkan suatu perhitungan berdasarkan tingkat kesesuaian antara harapan dan kenyataan fasilitas di Pantai Lasiana yang diterima. Dalam melakukan analisis data ini akan dilakukan dengan bantuan komputer dengan menggunakan aplikasi SPSS.

Menurut Supranto (2011:241) tingkat kesesuaian adalah hasil perbandingan skor harapan dengan skor kenyataan/pelaksanaan, dengan rumus yang digunakan sebagai berikut.

$$
\mathrm{Tki}=\frac{\mathrm{Xi}}{\mathrm{Yi}} \times 100 \%
$$

\section{Keterangan :}

Tki = Tingkat kesesuaian responden

$\mathrm{Xi}=$ Skor penilaian kinerja pelayanan yang diterima

$\mathrm{Yi} \quad=$ Skor penilaian kepentingan masyarakat

Diagram kartesius yang merupakan suatu bagian persegi empat bagian yang dibatasi oleh dua buah garis yang berpotongan tegak lurus pada titik-titik $(\mathrm{x}, \mathrm{y})$ dimana $(\mathrm{x})$ merupakan ratarata dari rata-rata skor tingkat kenyataan/kinerja seluruh faktor atau atribut dan (y) adalah ratarata dari rata-rata skor tingkat kepentingan seluruh faktor yang mempengaruhi harapan wisatawan, maka rumus selanjutnya sebagai berikut : 


$$
\overline{\mathrm{X}}=\frac{\sum \sum_{\mathrm{i}=1}^{\mathrm{N}} \overline{\mathrm{Xi}}}{\mathrm{K}} \quad \overline{\mathrm{Y}}=\frac{\sum_{\mathrm{i}=1}^{\mathrm{N}} \overline{\mathrm{Yi}}}{\mathrm{K}}
$$

$$
\begin{aligned}
& \text { Keterangan : } \\
& \quad \mathrm{K}=\text { Banyaknya faktor yang dapat mempengaruhi harapan pelanggan. }
\end{aligned}
$$

Selanjutnya tingkat unsur-unsur tersebut dijabarkan dan dibagi menjadi empat bagian kedalam diagram kartesius dengan bantuan komputer dengan menggunakan aplikasi SPSS sebagai berikut.

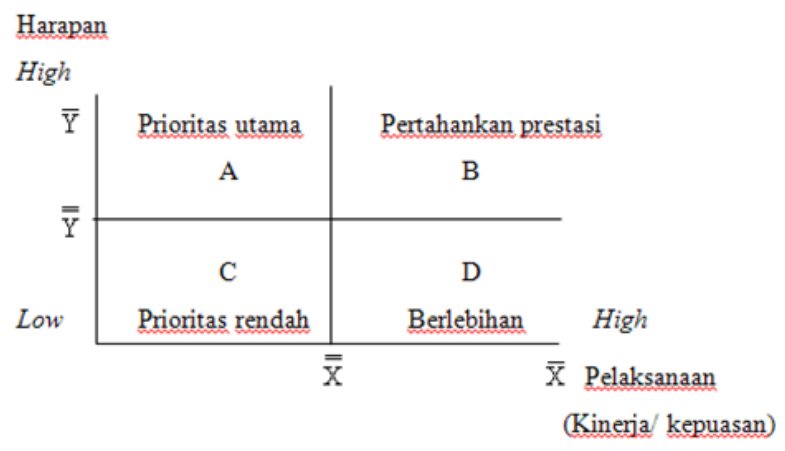

Gambar 2. Diagram Kartesius

Keterangan.

A. Menunjukkan faktor atau atribut yang dianggap mempengaruhi kepuasan wisatawan, termasuk unsur-unsur jasa yang dianggap sangat penting, namun pengelola belum melaksanakannya sesuai dengan keinginan wisatawan sehingga mengecewakan/tidak puas.

B. Menunjukkan unsur jasa pokok yang telah berhasil dilaksanakan. Untuk itu wajib dipertahankannya. Dianggap sangat penting dan memuaskan.

C. Menunjukkan beberapa faktor yang kurang penting pengaruhnya bagi wisatawan. Pelaksanaannya oleh pengelola biasa-biasa saja. Dianggap kurang penting dan kurang memuaskan.

D. Menunjukkan faktor yang mempengaruhi pelanggan kurang penting, akan tetapi pelaksanaannya berlebihan. Dianggap kurang penting tetapi sangat memuaskan.

Fasilitas pariwisata menjadi bermanfaat apabila sesuai dengan harapan pengunjung dan pelaksanaannya dirasakan sangat sesuai terletak pada kuadran B. Dalam penelitian ini notasi (y) yang berarti kepentingan disesuaikan dengan kebutuhan penelitian yang berarti harapan (y $=$ harapan) dan notasi ( $\mathrm{x}$ ) yang berarti kepuasan disesuaikan menjadi kenyataan ( $\mathrm{x}=$ kenyataan).

\section{HASIL PENELITIAN DAN PEMBAHASAN}

\section{Uji Validitas}

Dalam penelitian ini dilakukan uji validitas terhadap kuisioner tingkat kepentingan dan tingkat kinerja. Tabel dibawah ini menyajikan hasil uji validitas kuisioner kepentingan dan kinerja, dimana Corrected Item-Total Correlation ( $\mathrm{r}$ hitung) didapat dari hasil uji validitas dengan menggunakan aplikasi SPSS dan $\mathrm{R}$ tabel diambil dari tabel $r$ korelasi pearson sebesar 0,196 dengan taraf signifikansi 5\% disesuaikan dengan jumlah sampel sebanyak 100 .

Hasil uji validitas dapat dijelaskan bahwa semua item pernyataan pada kuisioner kepentingan mempunyai koofisien korelasi ( $\mathrm{r}$ hitung) $>\mathrm{r}$ tabel dengan nilai 0,196, nilai $\mathrm{r}$ hitungterendah 0,284 sehingga dapat dinyatakan bahwa semua item pernyataan sudah valid. 
Sedangkan pernyataan pada kuisioner kinerja atau kepuasan mempunyai koofisien korelasi ( $\mathrm{r}$ hitung) $>\mathrm{r}$ tabel dengan nilai 0,196, nilai $\mathrm{r}$-hitungterendah 0,266 sehingga dapat dinyatakan bahwa semua item pernyataan sudah valid.

\section{Uji Reliabilitas}

Dalam penelitian ini pengambilan keputusan berdasarkan jika nilai Alpha Cronbach > 0,6 maka pernyataan variabel tersebut reliabel dan sebaliknya. Nilai Alpha Cronbach untuk kuisioner kepentingan sebesar 0,739 dan kuisioner kinerja atau kepuasan sebesar 0,742. Dengan demikian kedua kuisioner tersebut memiliki nilai Alpha Cronbach lebih besar dari pada 0,6 sehingga dapat disimpulkan bahwa indikator yang digunakan untuk mengukur variabelvariabel tersebut dapat dihandalkan atau reliabel.

Analisis Tingkat Kepentingan dan Tingkat Kinerja Fasilitas Wisata di Obyek Wisata Pantai Lasiana

Puas atau tidaknya pengunjung terhadap kinerja fasilitas wisata di Pantai Lasiana diukur dengan menggunakan skala likert terhadap fasilitas wisata yang ada pada Pantai Lasiana. Karakteristik dan preferensi akan kebutuhan wisatawan yang berbeda-beda membuat wisatawan bisa saja merasa puas pada 1 atribut tetapi belum tentu puas terhadap atribut yang lain.

Dengan menggunakan metode Importance Performance Analysis (IPA) diharapkan berguna bagi pihak pengelola dan pengusaha di objek wisata Pantai Lasiana untuk mengetahui hal-hal apa saja yang masih harus ditingkatkan guna mencapai kepuasan para pengunjung yang datang ke objek wisata Pantai Lasiana. Melalui analisis ini dapat pula diketahui apa yang telah dirasakan dan bagaimana pihak pengelola bisa membuat perumusan strategi yang tepat untuk memperbaiki kinerja pelayanannya.

1. Tingkat Kesesuaian

Pada metode Importance Performance Analysis (IPA) terdapat perhitungan untuk menentukan urutan prioritas layanan, yang diukur dengan tingkat kesesuaian untuk menentukan prioritas perbaikan layanan terbaik untuk mencapai kepuasan konsumen. Untuk menghitung tingkat kesesuaian ini sebelumnya harus menghitung skor kinerja dan kepentingan setelah itu tingkat kesesuaian.Setelah dilakukan perhitungan, rata-rata tingkat kesesuaian yang didapat adalah $72,90 \%$. Dalam pengambilan keputusan, nilai rata-rata tingkat kesesuaian akan dibandingkan dengan nilai tingkat kesesuaian masingmasing atribut, apabila nilai tingkat kesesuaian atribut lebih kecil dari rata-rata tingkat kesesuaian maka atribut tersebut perlu adanya perbaikan dan bila nilai tingkat kesesuaian atribut lebih besar dari rata-rata tingkat kesesuaian maka atribut tersebutperludipertahankan.

Setelah dilakukan perhitungan, rata-rata tingkat kesesuaian yang didapat adalah 72,90\%. Dalam pengambilan keputusan, nilai rata-rata tingkat kesesuaian akan dibandingkan dengan nilai tingkat kesesuaian masing-masing atribut, apabila nilai tingkat kesesuaian atribut lebih kecil dari rata-rata tingkat kesesuaian maka atribut tersebut perlu adanya perbaikan dan bila nilai tingkat kesesuaian atribut lebih besar dari rata-rata tingkat kesesuaian maka atribut tersebut perlu dipertahankan.

2. Analisis Kuadran

Menghitung rata-rata penilaian tingkat kepentingan (importance) dan kinerja (performance) untuk setiap item atribut. Dalam analisis kuadran ini digunakan rumus :

$\overline{\mathrm{X}}=\frac{\sum \mathrm{X}_{\mathrm{i}}}{\mathrm{n}} \quad \overline{\mathrm{Y}}=\frac{\sum \mathrm{Y}_{\mathrm{i}}}{\mathrm{n}}$

Keterangan :

$\mathrm{X}=$ Skor rata-rata tingkat kinerja 


$$
\begin{array}{ll}
\mathrm{Y} & =\text { Skor rata-rata tingkat Kepentingan } \\
\mathrm{Xi} & =\text { Skor penilaian kinerja } \\
\mathrm{Yi} & =\text { Skor penilaian kepentingan } \\
\mathrm{n} & =\text { Jumlah responden }(100)
\end{array}
$$

Menghitung tingkat kinerja dan tingkat kepentingan per item :

$$
\begin{aligned}
\text { Tingkat kinerja A1 } & =381: 100 \\
\text { Tingkat kepentingan A1 } & =3,81 \\
& =441: 100 \\
& =4,41
\end{aligned}
$$

\begin{tabular}{|c|c|c|c|c|}
\hline No Atribut & Skor Kinerja & $\begin{array}{c}\text { Tingkat Kinerja } \\
(\mathrm{Xi})\end{array}$ & $\begin{array}{c}\text { Skor } \\
\text { Kepentingan }\end{array}$ & $\begin{array}{c}\text { Tingkat } \\
\text { Kepentingan (Yi) }\end{array}$ \\
\hline A1 & 381 & 3,81 & 441 & 4,41 \\
\hline $\mathrm{A} 2$ & 342 & 3,42 & 419 & 4,19 \\
\hline $\mathrm{A} 3$ & 343 & 3,43 & 433 & 4,33 \\
\hline $\mathrm{A} 4$ & 331 & 3,31 & 429 & 4,29 \\
\hline A5 & 322 & 3,22 & 437 & 4,37 \\
\hline A6 & 346 & 3,46 & 456 & 4,56 \\
\hline A7 & 330 & 3,3 & 402 & 4,02 \\
\hline A8 & 319 & 3,19 & 435 & 4,35 \\
\hline A9 & 350 & 3,5 & 431 & 4,31 \\
\hline $\mathrm{A} 10$ & 331 & 3,31 & 454 & 4,54 \\
\hline A11 & 328 & 3,28 & 455 & 4,55 \\
\hline A12 & 321 & 3,21 & 446 & 4,46 \\
\hline A13 & 324 & 3,24 & 442 & 4,42 \\
\hline A14 & 333 & 3,33 & 411 & 4,11 \\
\hline A15 & 287 & 2,87 & 407 & 4,07 \\
\hline A16 & 272 & 2,72 & 419 & 4,19 \\
\hline A17 & 339 & 3,39 & 434 & 4,34 \\
\hline A18 & 327 & 3,27 & 418 & 4,18 \\
\hline A19 & 243 & 2,43 & 433 & 4,33 \\
\hline $\mathrm{A} 20$ & 243 & 2,43 & 439 & 4,39 \\
\hline $\mathrm{A} 21$ & 310 & 3,1 & 441 & 4,41 \\
\hline A22 & 211 & 2,11 & 436 & 4,36 \\
\hline Total & 6933 & 69,33 & 9518 & 95,18 \\
\hline Rata-rata & & $\mathbf{0 , 6 9 3 3}$ & & $\mathbf{0 , 9 5 1 8}$ \\
\hline
\end{tabular}

Untuk menghitung tingkat kinerja dan tingkat kepentingan item yang lain menggunakan cara yang sama seperti perhitungan tingkat kinerja dan tingkat kepentingan A1 diatas.

Menghitung rata-rata tingkat kinerja dan tingkat kepentingan :

$$
\begin{aligned}
\text { Rata-rata tingkat kinerja } & =69,33: 100 \\
& =0,6933 \\
\text { Rata-rata tingkat kepentingan } & =95,18: 100 \\
& =0,9518
\end{aligned}
$$

Tabel 2. Perhitungan Koordinat Kwadran

Dari perhitungan diatas, didapat rata-rata tingkat kepentingan dan tingkat kinerja dari setiap atribut dengan nilai rata-rata yang didapat tingkat kinerja sebesar 0,6933 dan tingkat kepentingan sebesar 0,9518 . 
Selanjutnya untuk menentukan posisi penempatan variabel kinerja dan kepentingan dilakukan perhitungan rata-rata tingkat kepentingan dan tingkat kinerja keseluruhan atribut dengan menggunakan rumus :

$$
\overline{\mathrm{X}}=\frac{\sum_{\mathrm{i}=1}^{\mathrm{N}} \overline{\mathrm{Xi}}}{\mathrm{K}} \quad \overline{\mathrm{Y}}=\frac{\sum_{\mathrm{i}=1 \overline{\mathrm{Yi}}}^{\mathrm{N}}}{\mathrm{K}}
$$

$$
\begin{array}{cl}
\text { Keterangan : } \\
\mathrm{X} \quad=\text { Skor rata-rata tingkat kinerja } \\
\mathrm{Y} & =\text { Skor rata-rata tingkat Kepentingan } \\
\mathrm{Xi} & =\text { Skor penilaian kinerja } \\
\mathrm{Yi} & =\text { Skor penilaian kepentingan } \\
\mathrm{K} & =\text { Jumlah Atribut/pernyataan (22) }
\end{array}
$$

\begin{tabular}{|c|c|c|c|}
\hline No & Pernyataan & $\begin{array}{c}\text { Tingkat } \\
\text { Kinerja } \\
\text { (Xi) }\end{array}$ & $\begin{array}{c}\text { Tingkat Kepentingan } \\
\text { (Yi) }\end{array}$ \\
\hline 1 & $\begin{array}{l}\text { Ruangan makan yang } \\
\text { bersih }\end{array}$ & 3,81 & 4,41 \\
\hline 2 & $\begin{array}{l}\text { Desain ruangan yang } \\
\text { menarik }\end{array}$ & 3,42 & 4,19 \\
\hline 3 & $\begin{array}{l}\text { Perabotan ( kursi dan } \\
\text { meja) yang memadai }\end{array}$ & 3,43 & 4,33 \\
\hline 4 & $\begin{array}{l}\text { Makanan dan minuman } \\
\text { yang tersedia di resto } \\
\text { dan cafe sesuai dengan } \\
\text { selera wisatawan }\end{array}$ & 3,31 & 4,29 \\
\hline 5 & $\begin{array}{l}\text { Kebersihan kantin / } \\
\text { tempat jajanan kuliner } \\
\text { dalam kawasan obyek } \\
\text { wisata }\end{array}$ & 3,22 & 4,37 \\
\hline 6 & $\begin{array}{l}\text { Kebersihan makanan di } \\
\text { kantin }\end{array}$ & 3,46 & 4,56 \\
\hline 7 & $\begin{array}{l}\text { Penataan kantin / } \\
\text { tempat jajanan kuliner }\end{array}$ & 3,3 & 4,02 \\
\hline 8 & $\begin{array}{l}\text { Kenyamanan kantin / } \\
\text { tempat jajanan kuliner }\end{array}$ & 3,19 & 4,35 \\
\hline 9 & $\begin{array}{l}\text { Ketersediaan kursi dan } \\
\text { meja di kantin/tempat } \\
\text { jajanan kuliner }\end{array}$ & 3,5 & 4,31 \\
\hline 10 & $\begin{array}{l}\text { Kebersihan toilet } \\
\text { umum }\end{array}$ & 3,31 & 4,54 \\
\hline 11 & $\begin{array}{l}\text { Pemisahan toilet untuk } \\
\text { pria dan wanita }\end{array}$ & 3,28 & 4,55 \\
\hline
\end{tabular}

Menghitung rata-rata tingkat kepentingan dan tingkat kinerja :

$$
\begin{aligned}
\text { Rata-rata tingkat kinerja } & =69,33: 22 \\
& =3,15 . \\
\text { Rata-rata tingkat kepentingan } & =95,18: 22 \\
& =4,32 .
\end{aligned}
$$

Tabel 3. Rata-rata Penilaian Tingkat Kepentingan dan Tingkat Kinerja 


\begin{tabular}{|c|c|c|c|}
\hline No & Pernyataan & $\begin{array}{l}\text { Tingkat } \\
\text { Kinerja } \\
\text { (Xi) }\end{array}$ & $\begin{array}{c}\text { Tingkat Kepentingan } \\
\text { (Yi) }\end{array}$ \\
\hline 12 & $\begin{array}{l}\text { Ketersediaan air bersih } \\
\text { di toilet }\end{array}$ & 3,21 & 4,46 \\
\hline 13 & $\begin{array}{l}\text { Kualitas air bersih di } \\
\text { toilet }\end{array}$ & 3,24 & 4,42 \\
\hline 14 & Tata letak lahan parkir & 3,33 & 4,11 \\
\hline 15 & $\begin{array}{l}\text { Kondisi fisik lahan } \\
\text { parkir }\end{array}$ & 2,87 & 4,07 \\
\hline 16 & $\begin{array}{l}\text { Pemisahan area parkir } \\
\text { berdasarkan jenis } \\
\text { kendaraan }\end{array}$ & 2,72 & 4,19 \\
\hline 17 & Tata letak lopo & 3,39 & 4,34 \\
\hline 18 & $\begin{array}{l}\text { Ketersediaan jumlah } \\
\text { lopo }\end{array}$ & 3,27 & 4,18 \\
\hline 19 & kondisi fisik lopo & 2,43 & 4,33 \\
\hline 20 & $\begin{array}{l}\text { Kondisi fisik tempat } \\
\text { sampah }\end{array}$ & 2,43 & 4,39 \\
\hline 21 & $\begin{array}{l}\text { Ketersediaan jumlah } \\
\text { tempat sampah }\end{array}$ & 3,1 & 4,41 \\
\hline 22 & $\begin{array}{l}\text { Pemisahan jenis tempat } \\
\text { sampah organik/non } \\
\text { organik }\end{array}$ & 2,11 & 4,36 \\
\hline Jumlah & 69,33 & 95,18 & Jumlah \\
\hline \multicolumn{2}{|c|}{ Rata-rata } & 3,15 & 4,32 \\
\hline
\end{tabular}

Dari perhitungan diatas dapat dilihat nilai rata-rata dari tingkat kinerja sebesar 3,15 dan tingkat kepentingan sebesar 4,32 yang menyatakan bahwa tingkat kinerja lebih kecil dari pada tingkat kepentingan. Oleh karena itu dapat disimpulkan bahwa fasilitas wisata yang ada di pantai Lasiana masih dibawa harapan para wisatawan.

Dari total yang didapatkan ini dijabarkan dalam diagram kartesius sebagai berikut.

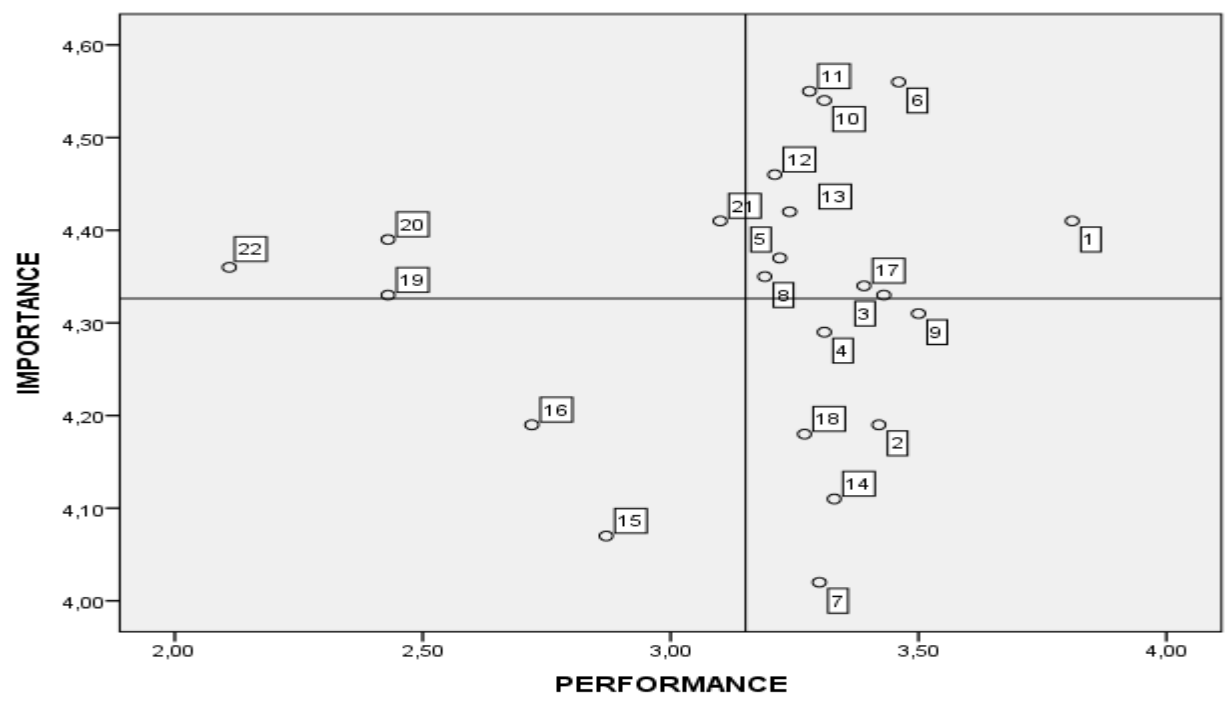

Gambar 3. Diagram Cartesius IPA Fasilitas Wisata di Pantai Lasiana 
Dalam gambar 3.1 dari diagram kartesius terlihat bahwa letak dari item-item kepuasan berdasar persepsi kinerja dan kepentingan terbagi menjadi empat kuadran. Interpretasi dari diagram kartesius tersebut dapat dijelaskan sebagai berikut.

1. Kuadran A

Dalam kuadran ini ditunjukkan perihal yang diprioritaskan untuk ditangani segera oleh pengelola, sebab perihal ini sangat penting oleh pengunjung sementara dalam kenyataan masih belum sesuai harapan. Faktor-faktor yang termasuk dalam kuadran A adalah fasilitas umum yang terdapat di pantai Lasiana yaitu :

- Kondisi fisik lopo

- Kondisi fisik tempat sampah

- Ketersediaan jumlah tempat sampah

- Pemisahan jenis tempat sampah organik/non organik

2. Kuadran B

Dalam kuadran ini ditunjukkan perihal yang perlu dipertahankan, karena pada umumnya tingkat pelaksanaan dari faktor telah sesuai antara harapan dan kenyataan yang dialami pengunjung. Atribut-atribut yang termasuk dalam kuadran B yaitu :

- Ruangan makan yang bersih

- Perabotan (kursi dan meja) yang memadai

- Kebersihan kantin/tempat jajanan kuliner

- Kebersihan makanan di kantin

- Kenyamanan kantin/tempat jajanan kuliner

- Kebersihan toilet umum

- Pemisahan toilet untuk pria dan wanita

- Ketersediaan air bersih di toilet

- Kualitas air bersih di toilet

- Tata letak lopo.

3. Kuadran C

Dalam kuadran ini ditunjukkan perihal pelayanan yang dianggap kurang penting bagi pengunjung karena pada umumnya kuantitas pelaksanaannya dianggap biasa-biasa saja. Atribut-atribut yang termasuk dalam kuadran $\mathrm{C}$ yaitu :

- Kondisi fisik lahan parkir

- Pemisahan area parkir berdasarkan jenis kendaraan.

4. Kuadran D

Dalam kuadran ini ditunjukkan perihal yang dinilai berlebihan oleh pengunjung atau wisatawan. Hal ini disebabkan karena wisatawan menganggap perihal tersebut tidak terlalu penting namun pelaksanaannya sudah dilakukan dengan baik. Atribut-atribut yang termasuk dalam kuadran D yaitu :

- Desain ruangan yang menarik

- Makanan dan minuman yang tersedia di resto dan cafe sesuai dengan selera wisatawan

- Penataan kantin/tempat jajanan kuliner

- Kenyamanan kantin/tempat jajanan kuliner

- Ketersediaan kursi dan meja di kantin/tempat jajanan kuliner

- Tata letak lahan parkir dan ketersediaan jumlah lopo.

\section{Pembahasan Hasil Penelitian}

Temuan rata-rata tingkat kesesuaian fasilitas wisata di Pantai Lasiana yaitu sebesar $72,90 \%$. Dalam hasil penelitian terhadap variabel fasilitas wisata masih terdapat beberapa item yang perlu mendapatkan perhatian oleh pengelola pantai sebagai prioritas utama kepuasan wisatawan. 
Berdasarkan diagram kartesius fasilitas wisata di Pantai Lasiana, item fasilitas yang termasuk dalam prioritas utama dan harus ditingkatkan kinerjanya yaitu: kondisi fisik lopo, kondisi fisik tempat sampah, ketersediaan jumlah tempat sampah, pemisahan jenis tempat sampah organik/non organik perlu diperbaiki atau dibenahi agar kepuasan wisatawan pada kategori tersebut dapat meningkat. Setiap wisatawan yang berkunjung ke Pantai Lasiana mempunyai penilaian masing-masing.

Berdasarkan tingkat kepuasan, wisatawan merasa tidak puas dengan fasilitas yang ada. Hal tersebut ditunjukkan dengan nilai harapan lebih besar dari pada kenyataan ( $Y>X$ ). Sehingga pengelola pantai perlu meningkatkan dan memperbaiki fasilitas yang ada agar wisatawan atau pengunjung merasa puas dengan fasilitas wisata yang ada.

\section{KESIMPULAN DAN SARAN}

\section{Kesimpulan}

Hasil dari pengukuran tingkat kepuasan wisatawan dengan metode Importance Performance Analysis (IPA) adalah tingkat kinerja lebih kecil dari pada tingkat kepentingan $(\mathrm{X}<\mathrm{Y})$ sehingga dapat dinyatakan bahwa kualitas fasilitas wisata yang ada di Pantai Lasiana masih dibawa harapan wisatawan dan wisatawan merasa kurang puas dengan fasilitas wisata yang ada di Pantai Lasiana.

Berdasarkan diagram kartesius terdapat atribut-atribut yang mempengaruhi kepuasan wisatawan dan dianggap sangat penting namun pelaksanaannya belum sesuai dengan keinginan wisatawan dan wisatawan merasa tidak puas yaitu : kodisi fisik lopo, kodisi fisik tempat sampah, ketersediaan jumlah tempat sampah dan pemisahan jenis tempat sampah organik/non organik. Atribut-atribut yang dianggap sangat penting dan pelaksanaannya sudah sesuai dengan keinginan wisatawan yaitu : ruangan makan yang menarik, perabotan (kursi dan meja) yang memadai, kebersihan kantin/tempat jajanan kuliner, kebersihan makanan di kantin, kenyamanan kantin, tempat jajanan kuliner, kebersihan toilet umum, pemisahan toilet untuk pria dan wanita, ketersediaan air bersih di toilet, kualitas air bersih di toilet dan tata letak lopo, atribut-atribut ini perlu dipertahankan oleh pengelola. Atribut-atribut yang kurang penting pengaruhnya bagi wisatawan dan pelaksanaannyapun kurang memuaskan wisatawan yaitu : kondisi fisik lahan parkir dan pemisahan area parkir berdasarkan jenis kendaraan. Kedua atribut tersebut perlu untuk ditingkatkan kinerjanya. Atribut-atribut yang dianggap kurang penting serta pelaksannaannya berlebihan tetapi sangat memuaskan wisatawan yang berkunjung yaitu : desain ruangan yang menarik, makanan dan minuman yan tersedia di resto dan cafe sesuai selera wisatawan, penataan kantin/tempat jajanan kuliner, ketersediaan kursi dan meja di kantin, tata letak lahan parkir dan ketersediaan jumlah lopo. Atribut-atribut ini dianggap kurang penting oleh wisatawan namun pelaksanaannya sangat memuaskan wisatawan.

Indikator fasilitas wisata yang memiliki tingkat kepentingan paling tinggi dengan kinerja yang rendah dan masuk dalam kategori prioritas utama perlu mendapat perhatian yang lebih dari pengelola dan perlu ditingkatkan kualitasnya. Indikator tersebut yaitu kondisi fisik lopo, kondisi fisik tempat sampah, ketersediaan jumlah tempat sampah dan pemisahan jenis tempat sampah organik/non organik.

\section{Saran}

Pengelola perlu melihat segala kekurangan fasilitas wisata yang ada di Pantai Lasiana dan meningkatkan kualitas fasilitas wisata yang ada dengan melakukan pembenahan ataupun penambahan fasilitas penunjang lainnya sehingga dapat meningkatkan kepuasan wisatawan yang berkunjung dan dapat menarik wisatawan dari berbagai kalangan. Kepuasan pengunjung pada suatu obyek wisata sangatlah penting. Oleh karena itu pengelola perlu meningkatkan indikator fasilitas wisata yang memiliki tingkat kepentingan paling tinggi dengan kinerja yang rendah dan masuk dalam kategori prioritas utama yaitu : kondisi fisik lopo, kondisi fisik tempat 
sampah, ketersediaan jumlah tempat sampah dan pemisahan jenis tempat sampah organik/non organik.

CATATAN. Makalah ini merupakan makalah terpilih dari SNIMA 42019 - Seminar Nasional Manajemen yang diselenggarakan oleh Prodi Manajemen, Fakultas Ekonomi dan Bisnis, Universitas Surabaya.

\section{DAFTAR PUSTAKA}

Ali, Syah Baginda (2016) Strategi Pengembangan Fasilitas Guna Meningkatkan Daya Tarik Minat Wisatawandi Darajat Pass (waterpark) Kecamatan Pasirwangi Kabupaten Garut. Skripsi. Universitas Pendidikan Indonesia

Arikunto, S. (2002). Metodologi Penelitian. Bina Aksara: Yogyakarta.

Dinas Pariwisata NTT, (2019). NTT Dalam Angka 2019, Kupang. Pemerintah Provinsi Nusa Tenggara Timur.

Isgiyanto, Awal (2009). Teknik Pengambilan Sampel pada Penelitian Non Ekserimental. Mitra Cendikia Press. Yogyakarta.

Kusmayadi \& Sugiarto, Endar (2000). Metode Penelitian dalam Bidang Kepariwisataan. PT. Gramedia Pustaka. Jakarta.

Marpaung, (2002). Pengetahuan Kepariwisataan. Alfabeta. Bandung.

Mill, Robert Christie, 2000, Tourist the International Bussiness. PT Raja Grafindo Persada. Yogyakarta.

Muljadi, A.J, (2012). Kepariwisataan dan Perjalanan. PT Raja Grafindo Persada. Jakarta.

Payangan, Otto R. (2014). Pemasaran Jasa Pariwisata. IPB Press. Bogor.

Soemitro \& Suprayitno (2018). "Pemikiran Awal tentang Konsep Dasar Manajemen Aset Fasilitas”. Jurnal Manajemen Aset Infrastruktur \& Fasilitas, Vol. 2, Sup. 1, Juni 2018, Hal. : 1-13.

Spillane, J, (1994). Pariwisata Indonesia : Siasat Ekonomi dan Rekayasa Kebudayaan. Penerbit Kanisius. Yogyakarta.

Sugiyono (2016). Metod0e Penelitian Manajemen. Alfabeta. Bandung.

Sugiyono (2005). Statistika untuk Penelitian. Alfabeta. Bandung.

Sumayang, (2003). Dasar-dasar Manajemen Produksi dan Operasi. Salemba Empat. Jakarta. Supranto, J. (2011). Pengukuran Tingkat Kepuasan Pelanggan. Rineka Cipta. Jakarta.

Suryadana, Liga, M \& Octavia, Vanny, (2015). Pengantar Pemasaran Pariwisata. Alfabeta. Bandung.

Susetyarini, O. \& Masjhoer, J.M. (2018). "Pengukuran Tingkat Kepuasan Wisatawan Terhadap Fasilitas Umum, Prasarana Umum, dan Fasilitas Pariwisata di Malioboro Pasca Revitalisasi Kawasan”. Jurnal Ilmiah Kepariwisataan, Vol. 12, No. 1, Januari 2018. 
(e)ISSN 2615-1847 (p)ISSN 2615-1839

Jurnal Manajemen Aset Infrastruktur \& Fasilitas - Vol.2, No.1, Maret 2018 